\title{
Strategi Program MagazineProgram Khazanah Edisi Ramadhan 2019
}

\author{
Khairunnisa ${ }^{1}$, Fatimah ${ }^{2}$ \\ ${ }^{1,2}$ Sekolah Tinggi Ilmu Komunikasi Indonesia Maju \\ Email correspondent: khairunnisadepok@gmail.com
}

\begin{abstract}
Abstrak
Industri pertelevisian merupakan industri kreatif yang setiap harinya menghadirkan berbagai macam program acara unggulan. Setiap televisi terdapat divisi program yang memiliki berbagai strategi dalam memproduksikan suatu program, pada bulan ramadhan stasiun televisi bersaing dalam memproduksikan sebuah tayangan dalam bentuk konsep kajian-kajian islami. Salah satu program yang yang bertajuk islami ialah Khazanah Ramadhan, dalam Bulan Ramadhan kali ini Khazanah mengusungkan tematis Al-Quran dalam pembahasan pada bulan Ramadhan 2019 dan strategi episode yang diusungkan pada hari pertama Ramadhan ialah terapi cahaya. Metode penelitian ini menggunakan penelitian kualitatif dengan desain deskriptif dan menggunakan pendekatan observasi dimana dalam pendekatan ini data yang digunakan adalah data primer dari hasil pengamatan, wawanacra, dan dokumentasi. Dalam hasil penelitian ini tayangan Khazanah Ramadhan di hari pertama dengan episode terapi cahaya memiliki strategi dalam teknik produksinya ialah, pra produksi, produksi, dan pasca produksi, yang tentunya berbeda dengan tayangan sebelumnya. Dalam menggunakan strategi tersebut tim produksi Khazanah dapat memberikan suatu tayangan yang bervariatif dalam segi pembahasan, segi liputan, dan hasil visual video. Dan selain itu Khazanah ramadhan tetap harus memperhatikan promosi dalam media sosial agar audiens lebih tertarik lagi.
\end{abstract}

Kata Kunci: strategi, proses produksi magazine, terapi cahaya

\begin{abstract}
The television industry is a creative industry that presents various kinds of excellent programs. Every television program division has a variety of strategies in producing a program, in the month of Ramadan television stations compete in producing a show in the form of Islamic studies concepts. One of the programs Islamic is Khazanah Ramadhan, in this Ramadhan Khazanah proposes the thematic Al-Quran in the discussion on Ramadan 2019 and the episode strategy that is put forward on the first day of Ramadan is light therapy. This research method uses qualitative research with descriptive design and uses an observation approach, wherein this approach the data used are primary data from observations, interviews, and documentation. In the results of this research, the first day of Ramadan Khazanah on light therapy episodes has a strategy production technique is pre-production, production, and post-production, which is certainly different from previous shows. In using this strategy the Khazanah production team provides a variety of shows in terms of discussion, in terms of coverage, and video visual results. And besides that, the Khazanah still has to pay attention to promotion in social media so that the audience is even more interested.
\end{abstract}

Keywords: strategies, process production magazine, light therapy 


\section{Pendahuluan}

Televisi merupakan media komunikasi modern dan perkembangan televisi saat ini pun sangatlah pesat. Televisi merupakan suatu media yang memiliki audiens yang paling besar tak hanya itu televisi menyuguhkan berupa audio-visual, dimana masyarakat akan mendapatkan informasi melalui suara (audio) dan diperkuat dengan gambar (visual). Yang kita ketahui bahwa dahulunya tayangan televisi berwana hitam putih namun dengan berkembangnya dunia teknologi elektronik kini kita bisa menyaksikan program acara lebih berwarna. Kurang lebih 13 Stasiuan televisi swasta di indonesia telah mengudara yakni, TVRI, RCTI, GLOBAL TV, MNC TV, INDOSIAR, SCTV, ANTV, TV ONE, TRANS TV, TRANS7, METRO TV, RTV, KOMPAS TV, dan lainnya. Berbagai pilihan program unggulan yang dihadirkan disetiap stasiun televisi. Setiap stasiun televisi akan memproduksi suatu program acara yang ditayangkan setiap harinya. Program-program yang dihadirkan sangatlah beragam diantaranya news, variety show, magazine show, talk show,dokumenter dan lainnya.

Televisi pun memiliki fungsi siaran tv sendiri, fungsi siaran tv disini mengarah betapa pentingnya dalam menyampaikan sebuah informasi kepada masyarakat indonesia. Fungsi siaran tv memiliki 4 poin utama yakni, menginformasikan infromasi secara fakta aktual dan terpercaya, yang kedua menghibur tentunya memberikan konten program yang membuat penonton terbawa suasana yang diberikan, ketiga memdidik dengan memberikan konten yang berupa quiz soal pelajaran ataupun memberikan informasi mendidik ditengah tengah jalannya program acara, dan terakhir ruang kontrol masyarakat suatu informasi yang belum pasti tidak akan ditayangkan dan akan dilakukan pedalaman terkait informasi yang akan ditayangkan. ${ }^{1}$

Program dalam konteks broadcasting merupakan suatu progam acara atau paket kajian yang berisi muatan kata terucap dan tertulis, gambar stastis dan bergerak, musik, efek suara, tata kamera ataupun audio serta tata cahaya dan lainnya yang disuguhkan atau disampaikan melalui media elektronik televisi kepada khalayak. Program juga mengandung pengertian dari acara atau perencanaan, pengorganisasian dalam periode harian, mingguan, bulan hingga tahun. ${ }^{2}$

Industri pertelevisian dituntut untuk menghadirkan konsep-konsep kreatif yang fresh disetiap porgram nya dan memiliki strategi dalam menghadapi persaingan program setiap harinya. Televisi akan menyajikan program unggulan yang inspiratif, informatif, dan menghibur maka hal tersebut akan berkaitan dengan rating dan share program tersebut. setiap program memilki fungsi tersendiri yaitu, menginformasikan (information) memberikan informasi secara fakta aktual dan terpercaya, menghibur (entertaiment) lebih kepada konten program yang membuat penonton terbawa suasana yang ditayangkan, mendidik (education) memberikan informasi yang mendidik disela- sela jalannya acara, serta sebagai ruang kontrol masyarakat (social control) lebih kepada memastikan suatu informasi yang tlah disebarkan via media sosial. Fungsi siaran tv itu sendiri dapat diartikan paling penting menyampaikan informasi kepada masyarakat. ${ }^{3}$

Dalam menggambarkan tentang berbagai jenis program siaran televisi secara umum dapat dibagi ke dalam dua bagian, yaitu program hiburan disebut dengan program entertaiment dan program informasi disebut juga dengan program berita news. Program informasi adalah program segala jenis yang bertujuan untuk memberikan pengetahuan dan menambahkan wawasan kepada audiens dengan informasi peristiwa yang terjadi disekitar kita ataupun luar negri. Program informasi dibagi lagi menjadi dua kategori program yakni, hard news dan soft news. Sedangkan program hiburan juga dibagi menjadi dua kategori yakni, drama dan non drama. ${ }^{4}$

Format acara televisi itu sendiri merupakan sebuah perencanaan dasar dari suatu konsep acara televisi yang akan menjadi landasan kreativitas dan desain produksi yang akan terbagi dalam berbagai kriteria utama yang disesuaikan dengan tujuan dan target pemirsa acara tersebut. acara yang bagus akan menjadi berantakan jika tidak disusuh dengan rapih, maka semuanya dapat diantisipasi dengan adanyan Format acara televisi. ${ }^{5}$

Format acara televisi pun terbagi menjadi 2 bagian yakni format stasion yang lebih mengarah pedoman dan pola ciri khas yang mendominasikan program tersebut, tujuannya lebih mudah membidik segmentasi yang dituju dan memudahkan pihak iklan ataupun sponsor untuk mempromosikan barang 
atau jasanya, Dan format program lebih mnegarahkan ke suatu program yang dicirikan dan didominasikan oleh elemen tertentu dalam suatu acara dan disesuaikan dengan jadwal penayangannya. ${ }^{6}$

Jika memproduksikan suatu program baru maka tim yang telah ditunjuk berserta direktur divisi porgramming akan menentukan program seperti apa yang diinginkan, dari format acara, team perdivisi program, konsep nya seperti apa dan berbagai peralatan jika menggunakan studio. Jika mengambilformat acara nondrama Magazine show maka dari itu pihak tim tidak perlu melakukan siaran secara live, hanya saja shooting sesuai dengan materi yang dibutuhkan untuk setiap tayangannya.

Program magazine show, program ini terdapat di dalam kategori program hiburan soft news. Magazine show sering disebut sebagai majalah udara, program yang menyuguhkan informasi ringan dan mendalam ini sangat berbeda dengan kategori program lainnya. istilah magazine adalah majalah, yang diangkat menjadi sebuah program yang memberikan informasi yang dikemas secara audio visual. Dalam pembahasan magazine show pada televisi terbilang cukup sulit untuk mempertahankan rating dan share nya. karna, dilihat dari minat masyarakat pun sudah mulai berkurang, jika konsep format program tersebut kurang mengambil hati audiens maka lambat laun program tersebut akan tidak ditayangkan lagi (Pree M). ${ }^{7}$

Maka setiap program memilki strategi untuk mencapai tujuan perusahaan. Strategi adalah rencana berskala besar, dengan orientasi masa depan guna berinteraksi dengan konsisi pesaing dan tindakan proses perencanaan untuk mencapai tujuan yang telah ditetapkan.15 Strategi pun merupakan perencanaan dan management suatu program untuk jangka panjang. ${ }^{8}$

Di industri penyiaran strategi digunakan untuk program dan berkompetisi dengan program stasiun televisi lainnya untuk memperebutkan audience. Strategi dalam suatu program televisi untuk memprediksi perkembangan dari programnya itu sendiri dan suatu keinginan mencapai tujuan dan memiliki sasaran target audiens, dan merencanakan suatu tindakan yang akan dilakukan esok hari. ${ }^{9}$

Dalam dunia televisi ada beberapa yang masih menggunakan strategi produksi pada program itu sendiri, guna untuk memperkuat isi konsep yang akan dikerjakan. Dalam strategi produksi itu sendiri merupakan stratei dalam produksi suatu program televisi untuk memprediksi perkembnagan dari programnya. Strategi ini merupakan suatu keinginan bersama untuk pencapaian tujuan dalam program televisi, dimana memiliki sasaran audience setiap programnya. ${ }^{10}$

Dalam tahapan produksi program dengan berformat acara magazine show ini tidak memerlukan equitment yang banyak, hanya memerlukan peralatan sesuai kebutuhan shooting. Proses tahapan produksi magazine show ini ada 3 tahap yakni, Pra produksi, Poduksi, dan Pasca produksi. Pra produksi atau tahapan perencanaan dan persiapan yang dilaksanakan secara terperinci dan menentukan suatu konten atau isi materi yang akan dibuat oleh reporter dalam bentuk naskah jadi. dan juga mempersiapkan biaya produksi, persuratan, administrasi penayangan, strategi penayangan hingga draft stock penayangan dan dubber. Produksi merupakan tahapan pelaksaan atau production adalah upaya mengubah naskah menjadi bentuk audio video (AV) dalam program magazine show yang mengarah kepada informasi dapat diproduksi tanpa set up atau reharseal, dan tahapan ini hanya seluruh tim work yang sudah dijadwalkan untuk shooting seprti kameramen, reporter, dan audio person. ${ }^{7}$ Dan tahapan terakhir Pra produksi yang merupakan proses penyempurnaan gambar melalui proses editting, mixing, dan quality control (QC). ${ }^{11}$

Dan stasiun televisi yang menghadirkan format acara magazine show dan program religi ditayangkan setiap harinya hanya Trans7. Biasanya televisi lainnya hanya menyangkan di bulan ramadhan saja. Program unggulan religi Trans 7 yaitu, khazanah, poros surga, ruqyah, islampedia, hijab traveling dan lainnya.

Trans7 merupakan stasiun televisi yang sebelumnya bernama Tv7 dan kini berganti nama menjadi Trans7. Trans7 menjadi televisi pilihan pemirsa indonesia dengan Positioning smart, entertaining \& family.4 Berbagai program pilihan Trans7 menjadi favorite masyarakat dirumah, salah satunya program religi yang hadir setiap hari sebelum masyarakat beraktivitas yakni Khazanah.

Khazanah ramadhan merupakan program acara dengan format magazine show religi, yang memadukan dakwah islam melalui visualisasi dan ilustrasi serta nasihat-nasihat dari ustadz dan ahli- 
ahli agama terkemuka ditanah air. Khazanah memiliki 2 jadwal tayangan yakni, khazanah (reguler) untuk setiap harinya dan khazanah ramadhan hanya untuk di bulan ramadhan bahkan untuk isi pembahasan keduanya sangatlah berbeda disetiap tayangannya. Khazanah reguler hadir disetiap hari senin-sabtu pukul 05.00-05.45 WIB, sedagkan untukn khazanah ramadhan senin -minggu 05.45-06.15 WIB. ${ }^{12}$

Dalam setiap penelitian harus memiliki teori komunikasi yang sesuia dengan penelitian yang kita lakukan, dalam hasil penelitian pada kali ini menggunakan teori komunikasi Laswell, Teori yang sederhana dan mudah dipahami dengan menggunakan unsur penting pada model ini. S-O-R (Stimulus= Pesan, Organims $=$ Komunikan, Response $=$ Efek). Dasar teori ini menjelaskan bagaimana proses komunikasi dapat bekerja secara sistematis sehingga hasilnya tepat sasaran. seperti halnya, siapa menyampaikan pesan dan pesan yang disampaikan, media apa yang digunakan, dan siapa penerima pesan tersebut. ${ }^{13}$

Program ini merupakan ensiklopedia islam dengan harapan dapat menjadi tontonan utama bagi umat islam di indonesia. Berbeda dengan program religi lainnya yang disuguhkan dalam bentuk ceramah, lomba dan talk show, sedangkan khazanah terletak pada bentuk tayangan dokumenter audiovisual yang terdapat vox pop, ilustrasi, voice over hingga diperkuat dengan pengemasan materi setiap episodenya. Khazanah ramadhan tahun 2019 ini mengusungkan tematis Al-Quran disetiap episodenya yang didesain ulang oleh produser agar lebih fresh dan memiliki tampilan cinematic dalam visualnya. Dan khazanah ramadhan masih menargetkan penonton dirumah sebaai audiodriven.

Dalam pengusungan tema ini produser hingga tim memiliki strategi dalam setiap tayangan dengan mengangkat cerita, kisah inspiratif, dari masyarakat hingga keajaiban Al-Quran dan etalase pembelajaran dengan Ust. Abu Rabbani yang memiliki teknik menarik sebagai narasumber beserta host. Episode pertama khazanah ramadhan menyuguhkan kisah inspiratif lansia yang membuat alat terapi dari cahaya dan lantunan ayat suci Al-Quran, yang merupakan strategi produser dan tim dalam penayangan ramadhan dihari pertama. Tentunya memposisikan suatu materi tayangan tidaklah mudah, karna setiap bulan ramadhan akan banyak sekali program religi yang ditayangkan setiap harinya.

Dalam penelitian ini penulis ingin mengetahui seperti apa strategi produksi dan proses produksi yang digunakan producer dan tim creative khazanah ramadhan di hari pertama ramadhan 2019 pada episode terapi cahaya, sehingga khazanah ramadhan masih menjadi pilihan masyarakat untuk program religi setiap tahunnya.

\section{Metode}

Metode penelitian yang digunakan dalam penelitian ini merupakan penelitian deskriptif dengan pendekatan kualitatif. Karna penulis ingin menguraikan serta mendeskripsikan mengenai bagaimana strategi hingga proses produksi magaine show pada program khazanah ramadhan episode terapi cahaya pada hari pertama bulan ramadhan 2019, hingga bagaimana mekanisme kerja dalam produksi tayangan program tersebut.

Pendekatan kualitatif adalah sebagai sumber produser penelitian yang menghasilkan data deskriptif berupa kata-kata tertulis atau lisan dari orang-orang dan perilaku yang dapat diamati. Dan, metode deskriptif ini merupakan penelitian yang mampu menghasilkan suatu uaraian mendalam tentang apa yang dilihat, tulisan atau lisan, didengar, dan tingkah laku dari suatu individu atau kelompok masyarakat, kemudian penulis baru mendata sepintas mengenai informasi yang diperolehnya. ${ }^{14}$

Sifat penelitian ini mneggunakan metode studi kasus, studi kasus adalah bagian metode kualitatif yang hendak mendalami suatu kasus tertentu secara lebih mendalam dengan melibatkan pengumpulan berbagai sumber informasi. ${ }^{15}$

Penelitian dengan menggunakan metode ini penulis merasa tidak ada jarak antara penulis kepada sumber informasi atau responden dalam menggali sebuah informasi sehingga penulis memiliki ruang untuk memahami obyek yang diteliti secara mendalam.

Sehingga Penulis ingin membahas secara khusus hal-hal yang mengenai strategi proses produksi 
program khazanah ramadhan di episode terapi cahaya pada hari pertama ramadhan 2019 dalam menarik hati penonton untuk tetap memilih khazanah ramadhan sebagai tontonan pagi harinya.

Data yang digunakan dalam penelitian ini dengan menggunakan data primer merupakan hasil dari meneliti atau observasi dengan teknik wawancara secara mendalam dan sekunder hasil dari pencarian dari tinjauan studi kepustakaan seperti buku atau jurnal terdahulu, dan teknik pengumpulan data yang digunakan ialah, observasi atau pengamatan secara langsung dalam berlangsungnya praktek kerja, wawancara sama dengan mengajukan sebuah pertanyaan yang berkaitan dengan rumusan masalah, dan dokumentasi berupa file-file ataupun foto. Hingga teknik pengolahan data dan analisis data menggunakan reduksi tahap ini penulis memilah infomasi mana yang relevan dan tidak relevan, penyajian data menyajikan data berupa uraian ataupun table, dan pengambilan kesimpulan merupakan penarikan kesimpulan dari hasil yang didapatkan.

\section{Hasil dan Pembahasan}

Trans7 adalah sebuah Stasiun Televisi yang sebelumnya bernama TV7. Stasiun TV ini Didirikan pada tanggal 22 maret 2000 dan di kelola oleh PT. Duta Visual Nusantara Tivi Tujuh, dan diluncurkan pertama kalinya pada tanggal 10 November 2001. TV7 kini berganti nama menjadi Trans7 yang dimana PT. Maka kemudian TV7 berganti nama menjadi Trans7 dan di launching ulang kembali pada tanggal 15 Desember 2006. TRANS7 menjadi televisi pilihan pemirsa Indonesia dengan positioning Smart, Entertaining \& Family. Dalam perjalanannya sampai dengan saat ini, siaran kami telah tersebar di 29 provinsi di Indonesia. Trans7 memiliki slogan "Aktif, Cerdas, Menghibur". Slogan ini memiliki makna Trans7 menjadi satu-satunya stasiun televisi yang aktif memberikan informasi yang cerdas dan memiliki wawasan. Dan makna lain pada slogan itu sebagai stasiun televisi yang inovatif dalam menayangkan berbagai jenis program acara yang sangat beragam, variatif, dan memberikan pengetahuan serta hiburan setiap programnya.

Program siaran Trans7 merupakan program yang mengunggulkan informasi yang menghibur, menarik, mendidik, dan inspiratif. Program yang ditayangkan tentunya beragam seperti, traveling, informasi/News, hiburan, entertaiment, dokumenter, religi dan lainnya. setiap menjelang bulan ramadhan pastinya Trans7 slalu menghadirkan program religi kembali. Salah satu program yang menjadi unggulan religi trans7 ialah Khazanah dan Khazanah Ramadhan. program ini hadir setiap hari dan juga bulan ramadhan dengan menghadirkan materi yang special. Khazanah merupakan program magazine show religi yang memadukan dakwah melalui visualisasi dan ilustrasi serta nasihat-nasihat dari ustadz dan ahli-ahli agama terkemuka ditanah air.

Ramadhan 2019 kali ini khazanah kembali hadir dengan nama program Khazanah Ramadhan, khazanah ramadhan sama saja dengan khazanah hanya saja khazanah ramadhan kali ini memiliki tematis yang special dengan tema Al-Quran. Hadir setiap hari senin-sabtu pukul 05.45-06.15 Wib. Setiap tayangan diberikan pembahasan informasi, kisah inspirasi, kabar viral, fenomena, yang menyangkut dengan Al-Quran, dan kali ini memberikan pelajaran membaca Al-Quran dengan Ust.Abu Rabbani salah satu pakar Al- Quran Learning di bandung. Khazanah ramadhan mengunggulkan informasi audio dan dipercantik dengan visual gambar setiap liputannya, informasi yang dibahasa ringan namun mendalam, dan menyelipkan suatu ayat Al-Quran atau[un dalil untuk meluruskan suatu permasalahan. Audio atau Voice over (Narasi) adalah keutamaan dalam memberikan informasi kepada penonton dirumah dan ilustrasi hingga vox pop.

\section{Tahapan Pra Produksi}

Sebuah program dapat dinyatakan berhasil atau tidak tergantung dari strategi yang digunakan oleh program tersebut. dalam proses pembuatan suatu tayangan akan diawali dengan tahapan dalam sebuah produksi, yakni Pra produksi, Produksi dan Pasca produksi. dalam tahapan pra produksi kali ini program khazanah ramadhan 2019 memiliki strategi yang menarik yang ingin membuat suatu pembahasan dengan mengusungkan konsep tematis Al-Quran pada bulan ramadhan tahun 2019. 
Tahapan pra produksi dilaksanakan secara terperinci dan baik, tentunya menentukan suatu konten atau isi materi naskah, lokasi shooting dan narasumber. Tahapan ini dilakukan setiap minggunya untuk pitching yang merupakan rapat seluruh anggota crew pada program tersebut dari executive producer hingga production assistant hingga penasehat untuk menentukan ide atau konsep materi, hingga strategi proram untuk kedepannya aka dibahas pada sesi pitching ini. Dalam tahapan pra produksi pitching kali ini khazanah ramadhan menentukan ide tematis ini producer dan assistant producer memikirkan kurang lebih 1 bulan untuk meyakinkan bahwa program khazanah bisa menayangkan tayangan yang menarik ditahun ini. Bulan ramadhan 2019 khazanah ingin menyajikan sebuah tayangan yang spesial dengan mengusungkan tema Al- Quran. Ramadhan merupakan bulan dimana turunnya Al-Quran oleh Allah SWT. Tidak hanya itu Al-Quran memiliki keunggulan pembahasan menarik dalam segi kajiannya, dan producer yakin bahwa tim khazanah memiliki sebuah info yang tidak dimiliki dan tidak dibisai oleh tv lainnya dan info yang dimiliki akan disampaikan oleh tim kepada penonton dengan gaya visual khazanah.

Dalam setiap menentukan informasi yang ingin ditayangkan pastinya tim kreatif ataupun reporter akan mencari sebuah informasi yang menarik untuk dibahas secara mendalam. Riset dan pembuatan naskah yang dilakukan oleh reporter bersamaan dengan pitching untuk menentukan dalil yang akan disisipkan dalam tayangan tersebut dan angle pembahasan infomasi yang diperdalam. Jika Al-Quran tidak terdapat dalil maka producer tidak berani untuk membahas secara mendalam. Dan informasi tayangan dihari pertama sudah dipersiapkan kurang lebih 2 minggu sebelum jadwal ditayangkan. Pada hari pertama tayangan yang sudah dijadwalkan ialah Terapi cahaya, producer memposisikan terapi cahaya dihari pertama ini merupakan info yang ringan dan menarik untuk dibahas, dan tentunya pembahasan itu bisa diikuti oleh banyak orang atau semua umur bisa menonton dibandingkan dengan pembahasan berikutnya. Terapi cahaya ini meruapakn suatu hal yang menarik karna terapi melalui cahaya dan secara bersamaan dilantunkan ayat suci Al-Quran. Yang diketahui bahwa Al-Qurn digunakan hanyan untuk ruqyah saja namun dalam tayangan ini Al-Quran dipergunakan sebagai Terapi. Dan untuk pembahasan lainnya tim khazanah biasanya melihat dari segi permasalahan di masyarakat terkait agama islam,fenomena alam, seperti halnya kehidupan sehari-hari yang selalu dipertanyakan.

Strategi yang digunakan pada tahapan pra produksi dan tayangan dihari pertama dengan episode terapi cahaya untuk meng-guide penonton untuk tetap stay dengan acara khazanah. dalam item ini meluruskan bahwa asumsi ketidaktahuan masyarakat mengenai keajaiban Al-Quran dan cahaya jika dipadukan memiliki keajaiban yang menarik.

\section{Tahapan Produksi}

Proses produksi merupakan proses peliputan atau eksekusi menjadi sebuah liputan yang berbentuk audio visual. Tahapan ini team yang dijadwalkan untuk shooting hanya reporter dan tim kameramen. Proses produksi yang dilakukan khazanah ramadhan pada episode terapi cahaya ini memiliki 4 tahap yakni, yang pertama Liputan interview by Appoitment, reporter sudah membuat janji kepada narasumber sebelum hari peliputan dimulai. Tim mengikuti kegiatan narasumber seharian untuk mendapatkan feel dari visual yang diberikan. Proses pengerjaan ini lebih mengarah kebagaimana proses cara kerja dari terapi cahaya ini. Liputan ini memakan waku 1 hari untuk satu pembahasan, tergantung tingkat kesulitan naskah dalam memvisualkannya. Yang kedua ialah Ilustrasi, ilustrasi ini digunakan untuk keperluan isi konten materi khazanah ramadhan saja. Tahapan ini membutuhkan seorang talent model untuk memperagakan setiap adegan yang sesuai dengan isi naskah per-scene, dan juga tim direct, reporter dan kameramen. Proses liputan ini memkan waktu kurang lebih 3 hari untuk 1 episodenya dihari pertama ramadhan. khazanah reguler ataupu khazanah ramadhan tetap menggunakan teknik ilustrasi ini sebagai tambahan informasi yang dibutuhkan pada pasca produksi. Yang ketiga Vox pop, vox pop merupakan teknik wawancara berdasarkan pertanyaan yang diajukan di naskah untuk mengetahui asumsi-asumsi ataupun pendapat masyarakat. Teknik ini merupakan strategi produksi dalam memberikan wajah baru pada tayangan khazanah ramadhan, yang merupakan kewajiban setiap tim liputan. 
Tujuan ini lebih tepat untuk meluruskan asumsi ketidaktahuan masyarakat mengenai seputar agama, fiqih, dana larangan yang dilarang olrh agama dan diluruskan oleh narasumber yang berkompeten seperti penasehat ataupun ustadz yang bekerja sama dengan khazanah. Yang ke empat proses Taping, taping biasa digunakan program acara berbasis show, dalam tayangan terapi cahaya proses taping sudah dikerjakan terlebih dahulu sebelum ditayangkan. Proses taping pada khazanah ini mengunakan teknik multi camera recording. Proses perekaman dilakukan dengan beberapa kamera pada satu adegan, biasanya lebih dari 3 kamera dengan pengambilan shot dan komposisi angle yang berbeda-beda. Khazanah ramadhan mengusungkan teknik taping ingin memberikan suatu pembelajaran kepada penonton dirumah bahwa belajar membaca Al- Quran hanya memerlukan waktu kurang dari 30 menit saja, dengan teknik bernyanyi yang diajarkan oleh Ust. Abu Rabbani.

\section{Tahapan Pasca Produksi}

Merupakan tahapan akhir dari seluruh rangkaian jalannya pembuatan program tv, dalam program acara magazine ini adalah proses penyempurnaan gambar hingga penayangan gambar. Dalam tahapan pasca produksi ini memiliki 3 rangkaian yakni, yang pertama editing tahapan penyuntingan gambar, pemotongan, penyambungan atau merangkai potongan gambar secara runtut dan utuh agar menjadi sebuah alur cerita. dalam proses ini seorang production assistant meng-guide naskah menjadi Voice over untuk mempermudah dalam pengeditan dan file berupa hasil shooting di back-up di komputer. Selain visual gambar ialah, naskah yang menjadi point utama dalam menjelaskan sebuah masalah, voice over juga merupakan point utama dalam pembahasan maka tahapan editing mensinkronisasikan voice over dengan visual yang sedang berjalan. Dan penambahan grafis ayat, menentukan musik hingga backsound yang tepat pada visual juga dilakukan pada saat editing. Yang kedua ialah Mixing, jika tahapan penyempurnaan alur cerita tlah selesai maka proses mixing dilakukan. Mixing berupa menyelaraskan, menyesuaikan, dan menyeimbangkan semua project edit dalam squence editing tersebut. tahapan ini akan di preview oleh porducer dan assistant producer dan dalam porses ini lebih memperhatikan kekurangan atau tidak diperlukan disetiap adegan. Barulah kepada tahapan rendering dan exporting, tahapan memperhalus dan mendapatkan hasil berupa video. Dan akan dikirim ke tahapan terakhir pasca produksi yakni QC (quality control), rangkaian akhir dari tahapan produksi pada program khazanah ramadhan 2019. QC akan mempreview ulang lagi video secara detail apakah ada adegan yang tidak layak tayang maka harus di proses editing ulang, jika tidak ada adegan yang dikhawatirkan maka $\mathrm{C}$ akan menambahkan tagline nama perusahaan di video tersebut sebagai hak paten milik perusahaan.

\section{Kesimpulan}

Program khazanah merupakan program berformat acara soft news dengan kategori magazine show. Yang menampilkan sebuah informasi pembahasan agama dengan mengusungkan tema Al-Quran disetiap informasinya. Khazanah dan khazanah ramadhan masih tetap hadir menemani penonton dirumah dipagi hari. Khazanah ramadhan tahun ini memiliki strategi produksi yang menarik sehingga rating dan share di hari pertama ramadhan dan satu bulan full ramadhan 2019 mendapatkan hasil yang baik. Strategi teknik produksi ialah pra produksi, produksi, dan pasca produksi.

Dalam pernyataan KPI bahawa khazanah masih terus diminati dari tahun 2015- 2016 yang memberikan perfoma terbaiknya setiap tahunnya. Dan strategi dihari pertama ialah episode terapi cahaya terbagi 3 item pembahasan yakni, terapi cahaya, ramadhan tempat diturunkan Al-Quran, dan pembelajaran membaca ayat Al-Quran oleh Ust. Abu Rabbani sebagai narasumber dan host dalam konsep talkshow dan menampilkan grafis ayat dengan teknik karaoke.

\section{References}

1. Fachrudin, Andi. Dasar-dasar penyiaran. Prenada Media Group, Jakarta. H.127. 2012

2. Hidajanto, Djamal. Dasar-Dasar penyiaran, Prenada Media Group. Jakarta. 2011

3. Alimudin, Andi. Televisi, masyarakat \& pluralistik. Prenada Media Group, Jakarta. 2014

4. Latief, Rusmandan Yusiatie utud. Siaran televisi Non-Drama. Prenada Media Group, Jakarta. 2015 


\section{JIKOM \\ Jurnal Ilmiah Komunikasi}

Volume 12, No.01, Maret. 2020

5. Naratama. Menjadi sutradara televisi. Grasindo, Jakarta. 2006

6. KN, Anton Mabruri. Penulisan Naskah Acara TV Non-Drama. gramedia, jakarta. 2009

7. KN, Anton Mabruri. Manajemen Produksi Program Acara Tv. gramedia, jakarta. 2010

8. Syaifudin, Nurul Wulan. Jurnal, Strategi Kratif dalam Memproduksikan Tayangan. 2017

9. Wulandari, S. Strategi Produksi program "Talkshow" Obrolan Karebosi di Celebes TV Makassar. Skripsi. Fakultas Dakwah dan Komunikasi. UIN Alauddin: Makassar. 2016

10. Mufid, Muhammad, Komunikasi dan Regulasi Penyiaran, Kencana Predana Media Group. Jakarta. h.23. 2010

11. Wibowo, Fred. Teknik Produksi Program Televisi, Yogyakarta: Pinus Book Publisher. 2007

12. Website Trans 7 (Program Khazanah) (https://www.trans7.co.id/programs/khaza nah)

13. Kurniawan, Dani. Jurnal. Komunikasi Model Laswell dan Stimulus-Organism- Response dalam Mewujudkan Pembelajaran Menyenangkan,S2. Ilmu Komunikasi. Universitas Sebelas Maret. 2018

14. Ruslan, Rosaady. Metode Penelitian PR dan Komunikasi. Jakarta: PT. raja Grafindo Persada Triartant.;2003

15. Fatimah, Fatimah. "Komunikasi Persuasif Agen Asuransi Dalam Merekrut Calon Agen (Studi Kasus Tentang Perekrutan

16. Calon Agen Dalam Meningkatkan Penjualan Polis di Asuransi PT. AXA)." Jurnal Ilmiah Komunikasi (JIKOM) STIKOM IMA 10.02 (2018): 110-116. 